\title{
FERAL ATLAS ACCELERATED
}

\author{
Æstetiske, konceptuelle og navigatoriske aspekter
}

\section{PERLE MØHL}

Jeg kaster mig ind i elektronernes fortryllende univers, siddende, som så ofte for tiden, foran min kompjuter. Jeg må rejse i det digitale, hvor virusser indtil videre ikke smitter mit kødelige legeme direkte. Jeg er fuld af forventning, jeg har fulgt forskningsprojektet på afstand og visuel antropolog Jennifer Degers fantastiske og yderst kreative arbejde med sine yolngukolleger (fx Deger 2006, 2016; Miyarrka Media 2020) på nærmere hold. Og jeg har løbende hørt om anstrengelserne med at få alle lag og elementer og idéer og koncepter og medier og indsigelser til at flyde sammen i et større virtuelt hele. Jeg er spændt, som stod jeg i en lufthavn med mit pas, på vej steder hen.

Jeg sætter mig og spænder selen. Og klikker på linket, ready for takeoff. Der accelereres, inden tyngdekraften ophæves. Der er ikke nogen „safety on board“folder at studere, jeg ved ikke, hvor nødudgangene er, eller om der falder ilt ned fra loftet ,in case of emergency“. Jeg lukker øjnene. Og så bølger jeg ud i ursuppen og skylles gennem rør og forbindelser, synker igennem, hiver efter vejret. Og lander pladask i et farverigt landskab, ør og lettere forvirret.

Ja, man kan bevæge sig ud i verden på to måder (m.fl.): Man kan studere kortet og rejsehåndbogen hjemmefra og have det fulde overblik over ruter og steder og navne og seværdigheder på forhånd. Eller man kan vælte sig ud i landskabet uden den mindste forberedelse andet end rejselyst og vovemod. Og det samme kan man gøre, når man giver sig i kast med et værk såsom en digital platform. Jeg vælger sidstnævnte strategi. Jeg er trods alt opdagelsesrejsende og med på den værste.

Jeg fanger en frø i ursuppen og følger med den over i accelerationens landskab.

Inden jeg rejser videre og bliver væk: Lad mig gratulere arbejdsgruppen bag Feral Atlas for at kaste sig ud i det enorme og komplekse arbejde, det er at udtænke og producere en digital multimedieplatform, som ovenikøbet samler resultater fra 
et langt og omfattende forskningsarbejde med mange deltagere og fra en række andre, forbundne projekter. Sådanne tiltag er der mildt sagt langt imellem. ${ }^{1} \mathrm{Og}$ guderne (dem på Valhalla) skal vide, at det kræver uhyrlige mængder tid, og at man som regel ikke høster de store akademiske laurbær, endsige avancementer for den slags forskningsformidling. Så tillykke til arbejdsgruppen for initiativet og det store arbejde.

Desuden fremstår Feral Atlas meget smukt og legende, med en masse gode idéer og æstetisk behagelige konkretiseringer af ofte abstrakte principper. Det gælder for eksempel arbejdet med at løsrive sig fra det scriptede og gennemstrukturerede for i stedet at arbejde med og indføre det tilfældiges spil - serendipitet - i den besøgendes navigation og i elementernes sammentræf. Det er netop en af det digitales og multimediales forcer, at man kan sammenstille og forbinde på kryds og tværs, nogle gange også på tilfældig vis. Der er ikke én måde at „læse“ - eller skal vi sige „besøge“? - dette atlas på, og hver gang man vender tilbage, vil man føres ind ad nye stier og møde nye beboere. Beboerne kan man definere som de elementer, atlasset er bygget op af, de veje, man ledes igennem det ad, og de mennesker, man møder der, både forfattere og beskrevne ... Nej, mest forfattere - for der indgår faktisk stort set ingen mennesker i dette vildskaben-i-menneskets-ruiner-atlas. De var der før og lagde grundstenene til alt det vilde, der sprang ud af eller genopstod i deres spor. Med forfattere mener jeg alle dem, der har bidraget med elementer, uanset format. De har forfattet idéer, tekster, billeder, tegninger, struktur, forbindelser, kode, og meget mere.
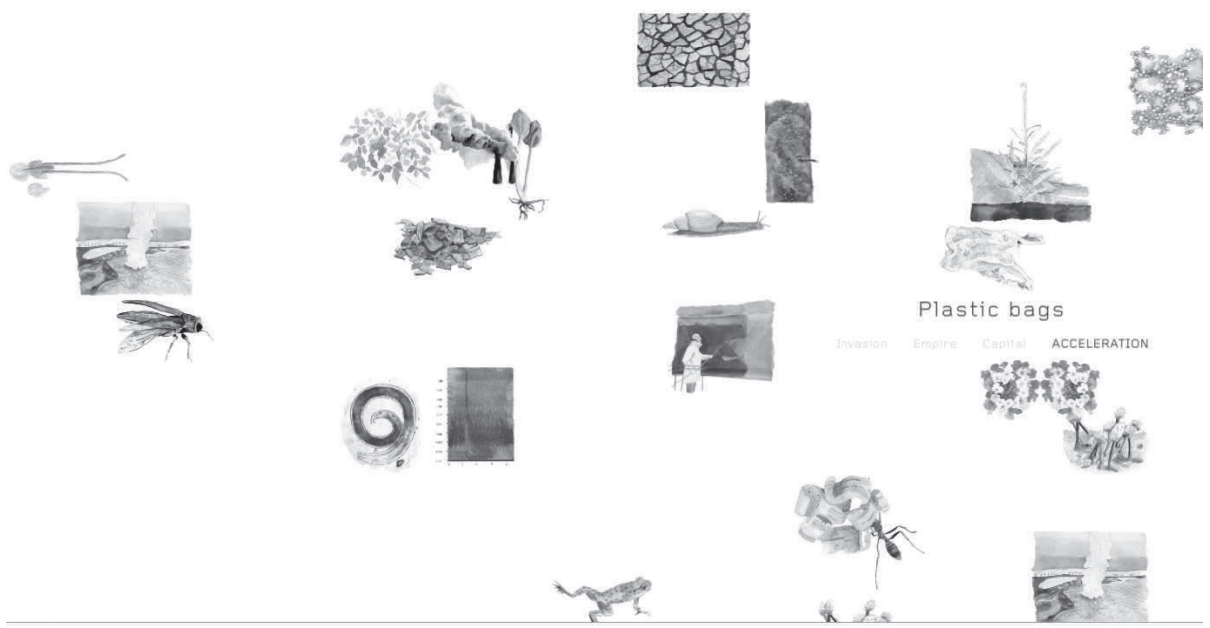

Figur 1. Ursuppen. Først er der intet (siden er hvid), så fyldes den langsomt med elementer, som flyder rundt imellem hinanden på må og få. 
Når alt dette prisende er sagt, så må jeg sige, at jeg tror, udviklerne har taget munden for fuld - og dermed, at vi som besøgende også får stoppet munden, og især øjne og ører, for fulde. De vil for meget. De vil for meget og vil have for meget med, og de vil lade tilfældighederne råde - ligesom i de ferale verdener, de beskriver - men samtidig aner man jo, som i al god forskning og formidling, at der ligger nogle klare intentioner bag projektet og nogle klare idéer om, hvordan der skal navigeres. At de vil os noget. At der er nogle bestemte ting, som det er værd at vide, og som vi skal lære ved at rejse igennem atlasset. Denne intention fremstår dog især i teksterne. Den fremstår i de fire „detonatorer“, som de arbejder med, og som tilsyneladende organiserer elementerne - men selve denne organisering er ganske svær at få øje på endsige at følge, hvis man ankommer som rejsende via hoveddøren, det vil sige ,ursuppen“. Den fremstår i den indledende, ganske korte tekst (som efterfølges af en meeeget lang rulletekst). Den fremstår i de ofte aldeles kryptiske tekster om det ferales principper og i de såkaldte „tippers“, syv af slagsen - BURN, CROWD, DUMP, GRID, PIPE, SMOOTH \& SPEED og TAKE. Og den fremstår i de ofte temmelig lange ,feltrapporter“ - 79 af slagsen, læser jeg senere - som man til sidst havner i efter den indledende vildførelse og flyden rundt blandt frøer og bakterier og katte og plastikposer (figur 1) - alle sammen yndigt tegnet og svævende rundt på må og få som i en mærkeligt transparent (hvid) ursuppe - indtil én enkelt standses af den besøgendes mus/cursor og ved et klik kan føre videre til næste lag eller tipper, eller hvad det nu er ... ja, ganske hæsblæsende.

Generelt veksler vi mellem mere eller mindre tunge tekster/feltrapporter, nogle med fotografier, andre med eller i form af filmuddrag, en masse tegninger og fotografier, de såkaldte ,video poems“ - 1-2 minutters optagelser af landskaber og elementer i dem, ofte filmet med drone, nogle gange med lyd og af varierende interesse - og små ordpoesier samt forbindelserne imellem alle disse elementer. Desuden kan man tilgå et Reading Room med forskellige essays samt alle de tekster, atlasset indeholder. Og så er der et yderligere lag, Feral Qualities, som giver endnu et perspektiv på „hvordan ferale økologier virker“. Og faktisk endnu ét, opdager jeg nu: det antropocænes land-, hav- og luftskaber. ${ }^{2}$ Men det er, som om tegningerne - det vil sige de to første lag, man kommer igennem, først „suppen“ med alle de små elementer og så detonatoren/tegningen, som elementet, man vælger, fører over i - og dernæst videodigtene, som man derefter bliver ført forbi, fungerer mere som smukke omveje på ruten til selve indholdet: teksterne. Og det tilfældige anslås først og fremmest af elementerne, der „, suppen“ flyder rundt imellem hinanden i en algo-rytmisk ukoordineret dans, og af at der er $s a ̊$ mange forbindelser ${ }^{3}$ og sider, at man kun tilfældigt møder dem. Derimod bruger udviklerne ikke det tilfældiges lykketræf, ved at den besøgendes valg for eksempel kommer til at sammenstille - juxtaposere - forskellige elementer i at- 
lasset på tilfældig og nyskabende vis, der pludselig giver nye indsigter, eller ved at lade elementer følge efter hinanden, alt efter hvilket valg den besøgende tager. Både sammenstillingen af elementer og stierne/overgangene imellem dem er faktisk fastsat på forhånd.

Den helt overordnede konklusion er, sidder jeg og tænker i flyet på vej hjem, mens jeg igen leder efter ,safety on board“-folderen, at rejseorganisatørerne-alle udviklerne bag atlasset - har givet den gas og har villet for meget. Og det skaber et virvar, hvor forvirringen indtil videre (efter fire timers vandring, hvor jeg nok kun har besøgt 10-15 procent af værket) ikke har været produktiv i sig selv. Det kan forvirring og tilfældighedernes spil ellers godt være. Især når vi bevæger os ud i verden. At forvilde sig væk i gyder og tilfældigt snuble ned i uoverdækkede huller og glemte forbindelser. Men skal en digital platform mime denne verdens kompleksitet og forvirring? Jeg ville nok foretrække, at kurateringen var mere håndfast $\mathrm{og}$ overskuelig, og at udviklerne havde begrænset enten mængden af indhold eller sparet på nogle af de mange lag eller analytiske perspektiver. Det er, som om de har villet det hele på én gang. Som om de kun kom til at lave denne ene digitale platform i deres liv, og derfor skulle have have det hele med og afprøve alle navigationsprincipper i ét. Og undertegnede, som ellers er godt bevandret $i$ at designe og navigere i digitale platforme og WebDocs og har produceret nogle stykker efterhånden, bliver tabt på gulvet. Det er smukt, det er ambitiøst, det er massivt. Men det skal indtages i små doser, uden forventning om overblik - og det er måske også hensigten.

\section{Acceleration}

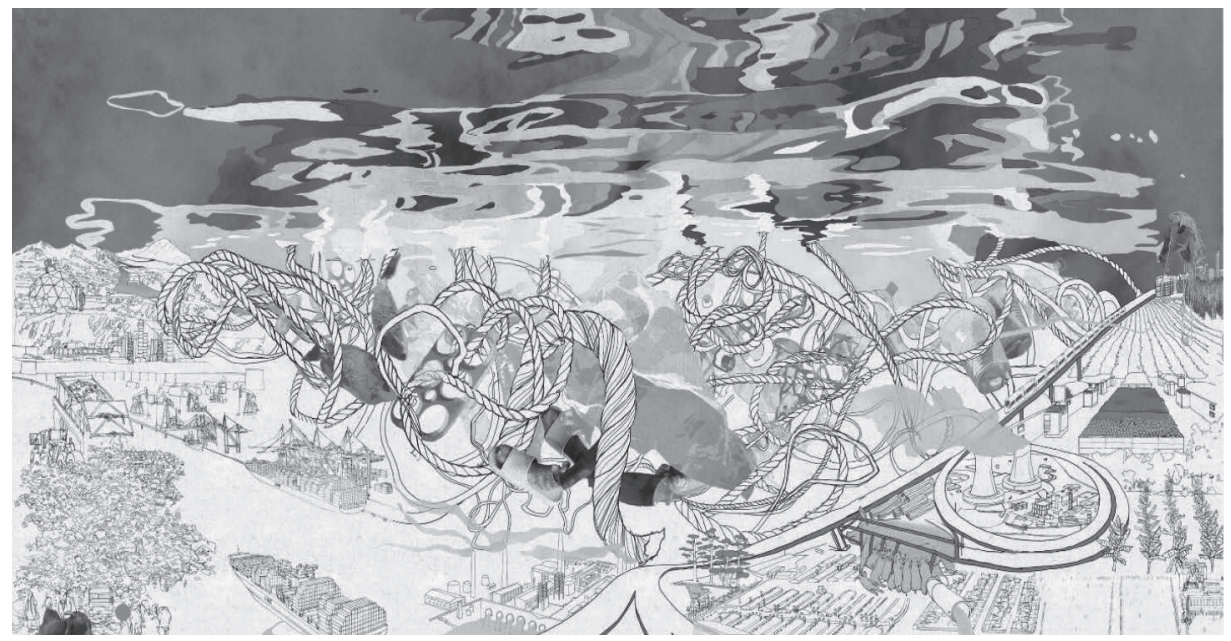

Figur 2. Acceleration landscape, med en rød prik, „discarded urban plastic“, svarende til elementet „plastic bags“, som jeg klikkede på i „ursuppen“ (se figur 1). 
Jeg skulle berejse den del af Feral Atlas, der omhandler acceleration. Men faktisk er det yderst kompliceret at udskille dette tema fra resten og dermed finde en rute, og det er nok heller ikke meningen, netop fordi det hele er forbundet.

Hvis jeg anlægger den velforberedte rejsendes (snyde)strategiske overblik, før rejsen overhovedet er begyndt, og således fiffigt klikker på ,acceleration“ inde i vejvisersuperindekset, kommer jeg da frem til en tekst om Hiroshima, kold krig, grøn revolution, imperialisme og industrialisme, aspekter af historien siden 1945, som har skabt det accelererede landskab, som vi ser i detonatoren/tegningen i figur 2. Desværre er der ikke hverken fra superindekset eller fra teksten om detonatoren/ tegningen noget link tilbage til selve detonatoren/tegningen, så den skal man finde - hvis man kan. Allerede her fortryder jeg overblikkets strategi-den anden vej ind, fra siden, virkede bedre.

Jeg går derfor tilbage til suppen (figur 1) og venter på et element, som betegnes ,acceleration“, og så klikker jeg og kommer over i detonatoren/tegningen (figur 2). Her kan jeg, hvis jeg ikke zoomer for meget ud, se, hvilke andre elementer der knytter sig til detonatoren ,acceleration“. De angives af små grå pletter. Her kan jeg så lede efter andre elementer for at prøve at forstå, hvad der specielt ligger i ,,acceleration“, som ikke ligger i „empire“-, „capital“- eller ,,invasion“detonatorerne. Det bliver dog aldrig helt klart. Et klik på en af de grå prikker vil så føre mig over i næste led med en af de syv tippers, lidt poesi og nogle videodigte. Og så videre til en feltrapport og måske til en anden tipper og tilbage. Men navigationen i detonatoren/tegningen er tilpas svær til, at jeg igen mister tråden. Skal jeg virkelig ty til teksten i enden - overblikskapitlet i rejsemanualen - for at forstå sammenhængene og forskellene? Skulle det ikke også komme til mig gennem oplevelsen? For igen, jeg sidder med den klare fornemmelse, at der er en masterplan, en overordnet betydningsmæssig intention, som jeg måske kunne fange, hvis jeg gennem superindekset tilgik alle teksterne og dem alene. Men jeg er her ikke for - og er ikke blevet inviteret til - at læse en bog.

\section{En kartografi af det antropocæne?}

Kortet er en art repræsentation af noget andet, et klassisk tegn, ofte todimensionel og som regel en nedskalering (medmindre det er Jorge Luis Borges' fantastiske kort, som i autoritetens og empiriets navn var en 1:1-repræsentation af landskabet, som det til sidst flød sammen med og blev en del af (Borges 1973)). Kortet er som alle semiotiske tegn en forenkling. Og det er samtidig en fortolkning af de ting, som ikke nødvendigvis kan ses med det nøgne øje i selve landskabet - ejerforhold, grænser, paragraffer, navne, tal, dominans, magt - som igen projiceres ud i det uforvarende landskab. I den forstand kommer landskabet - og subjekternes 
agens i det - til at repræsentere kortet: Vi standser her, in the middle of nothing, fordi der er en grænse på kortet, vi pløjer ikke der, fordi vi ikke ejer jorden, vi gemmer os her, fordi vi ikke har lov at være her. Og så videre. Der tegnes stier $i$ landskabet, $u d$ fra kortet. Den videndes øje er ikke længere nøgent. Den, som kender kortet, kan se grænserne, ejerskabet, dominansen.

Men er Feral Atlas en kartografi, en forenkling af noget andet, i dette tilfælde af et koncept, en vinkel på verden? Næppe. For det første er det ikke enkelt, snarere tværtimod - det virker mere komplekst end verden, selv den antropocæne, både at finde rundt $\mathrm{i}$ og at forstå sammenhænge og manglen på samme i. Så snarere end atlas og kort ville jeg betegne Feral Atlas som en parallelverden, med dets egne elementer, dets medier og dets forbindelser og uransagelige ormehuller, som alle allerede er udlægninger. Det er en villet verden, en styret verden, her er der som sagt en masterplan (og én master udvikler eller et panteon af udviklere (tilbage til Valhalla)) - den masterplan, som man i den sammensatte, posthumane tilgang har vænnet sig til ikke nødvendigvis at søge efter ude i verden, hvad man end forsker i. I atlasset er der en intention. Men rodet og vildfarelsen - som skam også er intentionel ${ }^{4}$ - er af en helt anden og digitalt koordineret art end den, vi kender andetsteds fra.

\section{Hjemme igen}

1) En så tæt pakket digital platform med så meget materiale, så mange medvirkende og så mange krydsveje og mellemstykker er ualmindelig svær at beskrive, især hvis man prøver at beskrive helheden og navigationen uden overblikket og uden at bruge teksterne som rollator - hvis man hengiver sig til det tilfældige, som atlasset også lægger op til.

2) Læseren må tage af sted selv, bevæbnet med skærm, mus, nysgerrighed og en del tålmodighed. For der er utvivlsomt meget at hente!

Og så kan man være spændt på, om udviklerne fortsat arbejder på værket og måske ville være åbne for ændringer. For en af de største fordele ved digitale platforme er nemlig, at de er evolutive og fortløbende kan bearbejdes og tilføres elementer. Således har coronavirussen sneget sig ind, også der, på trods af at værket stod stort set færdigt i foråret 2020. Udviklerne foreslår i læseværelset også, at atlasset bruges til undervisning, og der vil der nok komme løbende feedback. Så vi får se, om der eventuelt også bliver rettet op på nogle af de tekniske og navigatoriske problemer, som den besøgende støder på undervejs. 


\section{Noter}

1. Se for eksempel en artikel i Tidsskriftet Antropologi nr, 76, Genre, om det jeg kalder multigrafier, som er interaktive onlineplatforme, der samler og via forskellige organiserings- og navigationsprincipper sammen- og modstiller forskellige typer elementer: lyd, billeder, tekster, film, tegninger, diagrammer, data, kilder m.m. (Møhl 2017).

2. Land-, sea- and airscapes (https://feralatlas.supdigital.org/?cd=true\&bdtext=how-to-read-feralatlas).

3. og manglende forbindelser, som det også fastslås (det sidste skal jo nævnes, når man i en assemblage-antropologisk eller en mere-end-menneskelig kontekst taler om forbindelser, jeg gør mig selv skyldig heri). Dog giver det rigtig god mening at tale om manglende forbindelser, når vi kigger på fænomener $\mathrm{i}$ verden, men nok mindre, når vi diskuterer, hvordan nogle ting $\mathrm{i}$ et digitalt værk ikke rigtig synes at hænge sammen.

4. Og her ville jeg henvise til den side, der forklarer, hvordan man finder rundt i og bruger atlasset, men ... jeg kan simpelthen ikke finde den igen, end ikke i superindekset.

\section{Litteratur}

Borges, Jorge L.

1973 A Universal History of Infamy. London: Allen Lane.

Deger, Jennifer

2016 Thick Photography. Journal of Material Culture 21(1):111-32. DOI: 10.1177/ 1359183515623312 .

Deger, Jennifer

2006 Shimmering Screens. Making Media in an Aboriginal Community. Minneapolis: Minnesota University Press.

Miyarrka Media

2020 Phone \& Spear. A Yuta Anthropology. London: Goldsmiths Press. https://phoneand-spear.pubpub.org/.

Møhl, Perle

2017 Multigrafien og det multigrafiske projekt. Skitsering af en digital genre og dens potentialer. Tidsskriftet Antropologi 76:55-75. 